\title{
GIORDANO BRUNO AND THE ISLAMIC TRADITION
}

\author{
M.A. Francesco MALAGUTI \\ Ca' Foscari University of Venice, \\ ITALY, \\ Email: francesco.malaguti@alumni.unitn.it
}

\begin{abstract}
Giordano Bruno has been described as a philosopher, a mathematician, a poet and a mage: all of these terms depict a different aspect of the multi-faceted thinker he was. The development of his original and anti-dogmatic views is partly due to a constant confrontation with different philosophical, scientific and religious doctrines that Scholasticism did not share. Our aim in this article is to clarify the role of the Islamic tradition and its figures in relation to the thought of Giordano Bruno. There is no comprehensive study about this topic, though academics found a consistent connection between the philosophy of Bruno and Latin Averroism. Other topics concerning the Nolan philosopher and the Arabic sources deserve our attention: for example, aspects regarding the Western reception of Islamic science and pseudoscience (astronomy, astrology and alchemy in particular). Philological investigations establish that Bruno read Latin translations of Arabic works and found theories of medieval Muslim thinkers on secondary sources: in fact, he was familiar with authors like al-Ghazali, Avempace and Averroes, as he mentioned them in his works. In order to understand to what extent the Islamic tradition influenced Bruno, we analyzed and contextualized his references concerning the Arabs and the Persians. We concluded that he had an interest in the scientific and philosophical theories of the Muslims, but his overall view on Islam was vague and conditioned by the beliefs of his historical period. Moreover, we highlighted that Averroes was the only Islamic thinker who significantly influenced Bruno; though, the thought of the Nolan has more points in common with Averroism, rather than with the actual philosophy of Averroes.
\end{abstract}

Keywords: Islamic science in the West; Latin Averroism; Hermeticism; Alchemy; Astrology;

\section{INTRODUCTION}

As a European intellectual of the Renaissance, Giordano Bruno (1548 - 1600) lived in a Christian cultural context. The education he was given was also Christian, especially during his novitiate among the Dominicans at S. Domenico Maggiore in Naples ${ }^{1}$. After

\footnotetext{
${ }^{1}$ Before the Neapolitan period, Giordano Bruno never studied in a religious institute. Gian Domanico Iannello, the first teacher of Bruno, was a priest, though. For more information on the life of the Nolan, cfr. Vincenzo Spampanato, Vita di Giordano Bruno: con documenti editi e inediti, v. 1-2, Principiato Editore, Messina, 1921; Michele Ciliberto, Giordano Bruno, Laterza, Rome-Bari, 2005; Bertrand Levergeois, Giordano Bruno, tr. Manuela Maddamma, Fazi Editore, Rome, 2013. Bruno became a Dominican and was formally Catholic until he turned thirty years old, then he moved to Geneva and converted to Calvinism; later, he adapted himself to
} 
leaving the convent in 1576 , the philosopher started a travelling life and had the chance to meet thinkers from all over Europe. His interests in theology, philosophy and science (particularly the "new astronomy" of Nicolaus Copernicus) led him to extend his wisdom beyond the limits of his early education, regardless of the dogmas of Christianity. Apart from that, Bruno also came across themes of the other two major monotheisms.

During the Renaissance, the Latins knew many aspects of Judaism, also because of the presence of Jewish intellectuals at the courts, especially in Italy. Many Christian intellectuals even started to study Hebrew in order to understand religious texts. Indeed, there was a Christian kabbalistic tradition, which was represented by humanists like Giovanni Pico della Mirandola and Francesco Zorzi. Unlike the previously mentioned figures, the Nolan never showed a deep interest in those topics, even though a certain influence is noticeable. In The Cabala of Pegasus he mentions the sephiroth and aspects of Jewish angelology, but we should keep in mind that in the same dialogue we also find some harsh criticism against the Jewish tradition ${ }^{2}$. On the other side, the Nolan held the Jewish thinker Avicebron in esteem, though he believed he was a Muslim³ ; in fact, in De la causa, principio et uno, he mentions "a certain Arab called Avicebron, who shows that in a book called Fons vitae" ${ }^{\text {. }}$. This misunderstanding of Bruno and the Latins derives from the fact that Avicebron was Andalusian: in the Middle Ages, Christians, Jews and Muslims lived together in Andalusia. In that cultural context, a mutual exchange between three different cultures was possible. This also led to the spread of works concerning theology, philosophy and science throughout Europe. Beside the Jewish tradition, the Islamic one had an important role for the Christian world, if we consider the importance that Arab scientists and philosophers had for the Latins ${ }^{5}$.

The Nolan philosopher never visited the Islamic world. Nevertheless, he came across Islam-related themes and studied theories of Islamic intellectuals on primary and secondary sources. For instance, in his De umbris idearum, his first relevant philosophical work, he mentions the Muslim philosopher Averroes beside relevant Christian theologians such as Albert the Great and Thomas Aquinas, when he talks about the authors who played a role in his education ${ }^{6}$. As we are going to explain, the thought of Averroes and Averroism

Anglican and Lutheran contexts, as well. Surely, for him the concept of religion had the role of "social glue", as we are going to point out in the next pages about Bruno and Averroes.

${ }^{2}$ Cfr. Giordano Bruno, Cabala del Cavallo Pegaseo, edited by Nicola Badaloni, in Id., Opere italiane, v. 2, Utet, Turin, 2013, I, p. 438. Bruno defines the Jews as "vile, servile, mercenary people [which are] unable to communicate and be open for a dialogue with people of another lineage, which are bestially hated by them". Also see Id., Spaccio de la bestia trionfante, edited by Maria Pia Ellero, in Id., Opere italiane, v. 2, III-II, p. 362 (translation by the author): "It seems to me that that Jewish kabbalah is inspired by this [kind of magic], whose wisdom (whoever its discoverer is) is owned by the Egyptians, among which Moses studied". Jewish kabbalah is considered by Bruno as a deviant form of magic, therefore he negatively defines the Jews as "excrements of Egypt" (Ibid., III-II, p. 377), claiming that they simply borrowed a part of the ancient Egyptian wisdom for their purposes.

${ }^{3}$ Cfr. Felice Tocco, Le fonti più recenti della filosofia del Bruno, in Rendiconti della R. Accad. dei Lincei. Classe di scienze morali, storiche e filologiche, v. 1, n. 7/8 (1892), pp. 529-531.

${ }^{4}$ Giordano Bruno, De la causa, principio et uno, edited by Giovanni Aquilecchia, in Id., Opere italiane, v. 1, III, p. 678 (translation by the author).

${ }^{5}$ For a comprehensive overview about this topic, see: Julio Samsó, “Al-Andalus, a Bridge between Arabic and European Science", in Alhadra 1 (2015), pp. 101-125.

${ }^{6}$ Cfr. Giordano Bruno, De umbris idearum, in Id., Opera latine conscripta, edited by Imbriani-Tallarigo, v. 2, p. 1, Domenico Morano, Naples, 1886, p. 14. In this passage, Bruno mentions "Alulidis" (genitive case), which is a Latinized form of "al-Walid", one of the Arabic names of Averroes. 
surely played a relevant part in the philosophy of the Nolan, but many other references about Islamic themes and figures can be found in his works. Our purpose is to analyze and contextualize them one by one in order to get an overview of Bruno's knowledge of the Islamic tradition.

\section{ISLAM AND MUSLIMS}

Before focusing on specific figures like the previously mentioned Averroes, we introduce some general concepts concerning Islam that we found in the works of Giordano Bruno. In order of importance, we start talking about the god of Islam. Bruno mentions Allah in De Monade beside gods of other religions:

"IEOVAH and ADONAI among the Jews. THEUT among the Egyptians. ORSI among the Mages. SIRE among the Persians. THEOS among the Greeks. DEUS among the Latins. ALLA among the Arabs. GOTT among the Germanic peoples. DIEU among the Gauls. DIOS among the Hispanics. IDIO among the Italic peoples",

It is worth noting that all the names included in this sequence consist in four letters. That might be related to meaningful concepts of esotericism and magic: in particular, the biblical tetragrammaton (a divine name consisting of four letters) and the Pythagorean tetraktys (a triangular figure consisting of ten points arranged in four rows), which were connected in the kabbalistic tradition. Bruno is not the first who made this connection ${ }^{8}$. What matters to us now is the fact that he believed all religious cults and spiritual traditions to be branches of a single true religion - that is Marsilio Ficino's concept of prisca theologia which also present in the philosophy of Pico and Gemistus Pletho, among the intellectuals of the Renaissance. From that kind of view, different deities share the same role and common roots. Just like Ficino, Bruno inscribes different gods in the cult of Hermes Trimegistus, the ancient prophet who brought his secret wisdom to men in Egypt in an ancient past - at least according to a false myth that humanists made popular among themselves ${ }^{10}$. As we can see

\footnotetext{
${ }^{7}$ Id., De monade, numero et figura, in Id., Opera latine conscripta, edited by Francesco Fiorentino, v. 1, Domenico Morano, Naples 1879, V, p. 387 (translation by the author). The names "Ieovah" and "Adonai" consist in four letters, if they are written using the Jewish alphabet. The same goes for "Theut" and "Theos", if we use the Greek letter theta.

${ }^{8}$ About the relationship between Jewish kabbalah and Pythagoreanism, see the following studies: Moshe Idel, "Johannes Reuchlin: Kabbalah, Pythagorean Philosophy and Modern Scholarship", in Studia Judaica 16 (2008), pp. 30-55; Frances Amelia Yates, Giordano Bruno and the Hermetic Tradition, Routledge and Kegan Paul, London, 1964, p. 146 ff. In his De arte cabalistica, German kabbalist Johannes Reuchlin (1455 - 1522) explicitly connected the tetragrammaton with the tetraktys. Bruno never mentions Reuchlin explicitly, though philologist Felice Tocco claims that the philosopher knew the works of this kabbalist. Cfr. Felice Tocco, Le fonti, p. 534.

${ }^{9}$ Cfr. Marsilio Ficino, The Philebus Commentary, tr. M. J. B. Allen, University of California Press, Berkeley 1975, pp. 142-144: "Why everybody call God by four letters? The Hebrews by the four vowels "he ho ha hi"; the Egyptians by "Theuth"; the Persians by "Syre"; the Magi by "Orsi" whence "Oromasis"; the Greeks by "Theos"; ourselves by "Deus"; the Arabs by "Alla"; Mahomed by "Abgdi". Again we accepted "Jesu" from Gabriel [...] Surely such diverse races would not otherwise have agreed on the one name of the unknown God, unless they were divinely inspired? And if they received it from Adam, it was by divine inspiration they received that name rather than others." We find it natural to make a comparison with the previously quoted passage of De Monade. In the writings of Bruno, the implicit references to De vita coelitus comparanda and other works by the Tuscan neoplatonist are many. The Nolan was even accused of plagiarism in 1583 at Oxford: George Abbot claimed that his lectures on the immortality of the soul and on the quintuple sphere were based verbatim on Ficino's writings.

${ }_{10}$ Cfr. Frances Amelia Yates, Giordano Bruno and the Hermetic Tradition, ch. XXI (After Hermes Trismegistus was dated). In 1614, philologist Isaac Casaubon dated the Corpus Hermeticum and proved that
} 
by the previous quote, Allah is included in this syncretic view, as well: seemingly, Bruno does not distinguish the god of the Arabs from the others; in his perspective, they represent the same god - the god who revealed the truth to men in different cultures. This also explains why the Nolan counted Muhammad among figures prophets and notable men who have nothing to do with Islam, though they all represent people to whom the divine revealed himself $^{11}$. In the works of Bruno, we can also find references to the Arab phoenix. In the Arabic and Persian medieval world, the phoenix was a symbol for the divine essence or the search for the divine, though the origin of this figure is pre-islamic. The phoenix became a popular symbol in the Western world, as well. As other authors did in the Renaissance, Bruno used it as a literary figure and even wrote a poem on the Arabic mythological beast. It would be exaggeration to relate the presence of the phoenix in the writings of Bruno to the knowledge of Arab sources, though ${ }^{12}$.

A further relevant aspect concerning Islam in the works of Bruno is the awareness of the distinction between Sunni and Shia Muslims, the two main religious branches of Islam. In the Ash Wednesday Supper we can find a reference about this topic in a praise to Elisabeth I, queen of England:

\begin{abstract}
"“"[Elisabeth and other English politicians] can extinguish and banish darkness with the light of their great culture and, with the warmth of the loving courtesy, they can civilize and purify every rudeness and rusticity that can be found not only among Britons, but also among Shias, Arabs, Tartars, cannibals and antropophagists."13
\end{abstract}

Firstly, we point out that the "Shias" are distinguished by the "Arabs": by this last broad term, Bruno is probably referring to Sunnis, as they represent the majority of Muslims and the main pole of Islam. The opinion of the Nolan about Muslims in this passage seems to be negative, as he mentions them beside "barbarian" peoples. This is apparently confirmed in the so-called "hermetic lament" in The Expulsion of the Triumphant Beast:

"Egypt, of your religions only fables will remain, and they'll also be discredited by the future generations: the only thing that will tell them about your pious actions will be the letters

hermetic texts were written in post-Christian times. This discovery undermined the myths about Egypt and Hermes Trismegistus; it did not take effect immediately, because some intellectuals ignored or refused it. We point out that the echo of the hermetic texts in the Reinassaince was not so strong as Frances Yates claims in his study.

${ }^{11}$ Cfr. Giordano Bruno, De lampade combinatoria lulliana, in Id., Opera latine conscripta, edited by ToccoVitelli, v. 2, p. 2, Le Monnier, Florence 1890, p. 240. Beside Muhammad, Bruno mentions prophetic figures like Hermes Trimegistus, Moses and Zoroaster, but also historical figures like Plato and Romulus.

${ }^{12}$ Bruno mentions the phoenix in the Expulsion of the Triumphant Beast (I, III) and in the Heroic Frenzies (I, V). Cfr. Id., Gli eroici furori, edited by Nicoletta Tirinnanzi, BUR, Milan, 2015, I-V, p. 202:

"Unico augel del sol, vaga Fenice,/Ch'appareggi col mondo gli anni tui,/ Quai colmi ne l'Arabia felice,/ Tu sei chi fuste, io son quel che non fui./ Io per caldo d'amor muoio infelice;/ Ma te ravviv'il sol co' raggi sui./ Tu bruggi ' $n$ un, ed io in ogni loco;/ Io da Cupido, hai tu da Febo il foco./ Hai termini prefissi/ Di lunga vita, e io ho breve fine,/ Che pronto s'offre per mille ruine;/ Né so quel che vivrò, né quel che vissi:/ Me cieco fato adduce,/ Tu certo torni a riveder tua luce."

In the Renaissance, the phoenix was a symbol in alchemy and in literature - we can find it in the writings of notable Italian authors such as Ludovico Ariosto, Torquato Tasso and Francesco Petrarca. Furthermore, printers like Aldo Manuzio used to represent the phoenix in frontispieces. Cfr. Francesco Zambon \& Alessandro Grossato, Il mito della fenice in Oriente e in Occidente, Marsilio, Venice, 2004.

${ }^{13}$ Giordano Bruno, La cena de le ceneri, edited by Augusto Guzzo, Mondadori, Milan, 2012, II, p. 55 (translation by the author). By mentioning "Britons", Bruno is probably referring also to the conflict between Puritans and Anglicans; the philosopher held the queen in esteem, and then he was pro-Anglicanism. 
which are carved in stones, which won't tell anything about gods and men [...], but about Shias and Indians, or other similar savages" 14

One of the most important implications of Bruno's thought is the rejection of any "scale of nature" on the basis of which a certain being is somehow inferior to another. In fact, if God's creation is infinite, as the philosopher claims, then it is impossible to establish a hierarchy of being ${ }^{15}$ : then, man does not have a central position in the cosmos. A further consequence of this perspective is that an ethnic group cannot be inferior, neither superior to another. When the Nolan calls the Arabs and the Shias "savages", he does not mean that they are subhumans or something like that; in our opinion, he rather wanted to highlight their diversity compared to the Europeans, from an anthropological point of view ${ }^{16}$.

Apart from the differencies between the East and the West and their respective peoples, we already claimed that the cultural environments of these two worlds were both influenced by the works of intellectuals belonging to the tradition of the Arabs - some living in the medieval al-Andalus, some others not. We introduce them in the next paragraphs.

\section{ASTROLOGY}

Firstly, it is worth to mention the influence of the Islamic astrological tradition on the West. Islamic astrology was known in Europe especially from the $12^{\text {th }}$ century onwards, after the spread of the work De magnis coniunctionibus by Albumasar (787 - 886), a Persian author whose real name was in fact $\mathrm{Abu} \mathrm{Ma}$ 'shar. We shall remember that originally astronomy and astrology were indistinguishable: hence, in the theories of Albumasar we find the scientific concepts of determinism and naturalism. Beside of that, in his thought we can find superstitious beliefs, as well: Albumasar believed in the connection between the celestial phenomena of nature and the wordly affairs of men. His view has been summarized

\footnotetext{
${ }^{14}$ Id., Spaccio, III-II, p. 364 (translation by the author).

${ }^{15}$ In the philosophy of Bruno, creation is necessarily infinite. Claiming that God created a finite number of beings would mean that the divine power is also finite - which is unacceptable for the Nolan, for he considered God to be perfect and almighty. Cfr. Miguel Angel Granada, "Il rifiuto della distinzione fra potentia absoluta e potentia ordinata di Dio e l'affermazione dell'universo infinito in Giordano Bruno", in Rivista di storia della filosofia 49-3 (1994), pp. 495-532.

${ }^{16}$ An example of the anthropological perspective of Bruno and the concept of diversity is present in the following minor work: Giordano Bruno, De principiis rerum, elementis et causis, in Id., Opera latine conscripta, edited by Tocco-Vitelli, v. 3, Le Monnier, Florence, 1891, p. 555: "Sic etiam complexiones hominum in diversis locis diversae. Germani habent corpora generaliter proceriora, fortiora, bene colorata, sed tarda et gravia; Hispani generaliter breviora, sicciora, decolora, sed agilia. Ingenium quoque diversum est, quod hanc corporis diversitatem consequitur. Similes Hispanis hi qui habitant regiones magis australes, ut Mauri, Arabes [...]". The term "complexio" (which means more or less "physical structure") is present also in the Cabala of Pegasus, in which Bruno writes that the main difference between humans and animals is due to their respective atom-structure; there is no inferior or superior being, though. The same perspective can be applied to the debate on the native Americans. Cfr. Massimiliano Traversino, Sovranità in controluce. Bruno, Gentili e il dibattito cinquecentesco sulla condizione dei nativi americani, in Id. (eds.), Verità e dissimulazione. L'infinito di Giordano Bruno tra caccia filosofica e riforma religiosa, Editrice Domenicana Italiana, Naples, 2015, pp. 472473: "In a debate like the one which has arisen after the meeting of Europeans and native Americans, there were two main possible tendencies: on one side, the claim of animality and bestiality could be adopted to neglect them a full human nature and consider them as "natural slaves" [...] it was possible to claim, in contrast, that all peoples from all over the world share a "common bloodline". Ultimately, Bruno did not agree on either of those positions. If, of the first one, he did not share at all the idea of inferiority of the natives, he actually did not accept neither the second one. He rather believed in the diversity of those people, in contrast with the concept of inferiority."
} 
quite well by Ibn Khaldun, one of the most important Arab historiographers of the Middle Ages. Here below we give his significant account on astrology:

\begin{abstract}
"Astrologers, in making forecasts concerning dynasties, base themselves upon astrological judgments. For matters of general importance such as royal authority and dynasties, they use the conjunctions, especially those of the two superior planets. [...] The conjunctions of the two superior planets are divided into great, small, and medium. The great conjunction is the meeting of the two superior planets in the same degree of the firmament, which reoccurs after 960 years. [...] The great conjunction indicates great events, such as a change in royal authority or dynasties, or a transfer of royal authority from one people to another. The medium conjunction [indicates] the appearance of persons in search of superiority and royal authority. The small conjunction [indicates] the appearance of rebels or propagandists, and the ruin of towns or of their civilization"17.
\end{abstract}

As Ibn Khaldun claims, the political implications of astrological theories led humanists to incorporate eschatological and fatalist beliefs into their concept of history. This does not apply only for the medieval Islamic world, but also for the West during the Renaissance. In the specific case of Bruno, a connection between astrology and Hermeticism is quite evident in a passage of The Expulsion of the Triumphant Beast that we already quoted before:

"“' [Hermes Trismegistus is speaking to his disciple through Sofia.] Asclepius, do you see
these animated statues, full of meaning and spirit, which make those actions and many
worthy [other actions]? I mean these statues, which can foretell future events, cause disease,
cure, joy and sadness to moods and human bodies in accordance with what they deserve? Oh
Asclepius, don't you know that Egypt is the reflection of the sky and, to be exact, the colony
of all the things, which are ruled and applied in the sky? To tell the truth, our land [Egypt] is
the world's temple. But alas, there will come a time when Egypt will seem to have been in
vain lover of the deity: because the deity will move back to the sky through trasmigration
and leave Egypt desert and this divine throne will be widow of every religion, for it has been
abandoned by the presence of the gods, for there stranger and barbaric peoples without
religion, mercy, law or any cult will dominate. Oh Egypt! Egypt, of your religions only
fables will remain, and they'll also be discredited by the future generations: the only thing
that will tell them about your pious actions will be the letters carved in stones, which won't
tell anything about gods and men anymore but Shias and Indians, or other similar savages
(because they will be dead and the deity will be transmigrated to the sky)",18

In the hermetic lament, wars and changes in dynasties are not the only events determined by astral influences: the rise and the fall of religions is involved, as well. Here we have a description of Hermes Trismegistus' death and its consequences for humanity, which are both spiritual (the loss of wisdom) and political (the rise of barbarians). For our part, we consider these "fatalistic" descriptions as a part of the imaginary of the Renaissance. Bruno was not an astrologer, but he was fascinated by the astrology-related topics of Hermeticism, probably because they depicted a history of human culture. As he read the works of Marsilio Ficino and Cornelius Agrippa, Bruno probably knew also the Picatrix (Kitab ghayat al-hakim), a book of magic and astrology.

In the thought of the Nolan, the kind of "apocalypticism" we talked about is not the only topic in relation with astrology, as we are going to point out. The main concept behind The Expulsion of the Triumphant Beast may be connected to astrological beliefs. In the plot

\footnotetext{
${ }^{17}$ Ibn Khaldun, The Muqaddimah, tr. Franz Rosenthal, v. 2, Routledge \& Paul, London, 1958, pp. 212-213. Actually, Ibn Khaldun summarized Albumasar's Book of conjunctions in order to criticize him (and astrologers in general).

${ }^{18}$ Giordano Bruno, Spaccio, III, pp. 363-364 (translation and italics by the author).
} 
of the dialogue, the "triumphant beast" possibly symbolizes a constellation. The dramatis personae talk about vices placed in the sky; those vices shall be replaced by virtues in order to promote a moral revolution: again, we find the idea of heavenly bodies influencing the life of men on earth, though this is expressed only implicitly ${ }^{19}$.

A further example of the influence of astrology in Nolan philosophy are so-called wheels of memory, which can be found in De umbris idearum ${ }^{20}$ and other works on mnemotechnics: they show figures of astrological decans. Though, the weels of Bruno are different than the decans, as their main function is to make complex associations: they loose the symbolic meaning of the decans to get a more practical and rational use in relation with memory and language, which is almost in line with the exclusively mathematical approach of Copernican astronomy for some aspects (though, the Nolan criticized the theoretical approach of mathematics at least in Mordentius, De Mordentii circino, The Ash Wednesday Supper and Articuli contra mathematicos).

\section{ASTRONOMY}

While astrology influenced Bruno's ethics, mnemotechnics and concept of history, astronomy played a role in the development of his physical and cosmological doctrines. Regarding these topics, Bruno referred again to the theories of Albumasar, who was also an astronomer $^{21}$. In De immenso, his final work on the infinity of the universe, he wrote:

\footnotetext{
"Before these Italian astronomers, also Albumasar, among the Arabic peripatetics, believed that comets move above Venus. [...] Other people believe that there was a new star above Saturn which showed itself in the months of October and November; I've read their observation just as it has been made by the astronomers of Uraniborg." 22
}

This is a clear example of Bruno's criticsm against Aristotelianism. The Stagirite denied the possibility of the presence of comets beyond the sublunary sphere: from his perspective, a comet cannot move within the celestial spheres, for linear motion and corruption are sings of imperfection characterizing the sublunary spheres. Bruno believes that Albumasar was a peripatetic, but he was not. The Persian astronomer borrowed Aristotelian theories concerning physics and cosmology, but his opinion on comets was not "peripatetic" at all. It was in line with the discoveries of Tycho Brahe, the Danish astronomer who observed the transit of comets in 1577 and 1585 in the observatory of Uraniborg; at the time, Tycho Brahe was the first to deny the existence of celestial spheres. To Bruno, those observations were the final empirical confirmation to his doubts about Aristotelian cosmology. Other Muslim astronomers quoted by Bruno are the Arab al-Battani (c. 858 929) and the Persian Jabir ibn Hayyan (c. 721 - c. 815), also known as Geber in the Western

\footnotetext{
${ }^{19}$ Cfr. Eugenio Garin, Lo zodiaco della vita. La polemica sull'astrologia dal Trecento al Cinquecento, Laterza, Rome-Bari, 2007, pp. 122-126. Eugenio Garin suggests that astrology influenced Bruno's thought (particularly referring to mnemotecnics). Our considerations are a development of this line of thinking.

${ }^{20}$ The third part of Ars memoriae contains various descriptions of astrological figures with references to heavenly bodies. Bruno does not mention Albumasar, neither the Book of conjunctions, though.

21 Astronomy and astrology were closely linked in the Middle Ages and even more particularly in the Renaissance, as Garin points out. Cfr. Eugenio Garin, Lo zodiaco della vita (translation by the author): "[...] in the age of the Renaissance, within astrology there was a clear distinction between two aspects [...] which were often overlapped by the only term astrologia: the first aspect concerns religion and supestition, the second one is critical-scientific. In that way, predictive astrology [...] was finally isolated and defeated once and for all by mathematic astrology, i.e. the actual astronomy [...]"

${ }^{22}$ Giordano Bruno, De innumerabilibus, immenso et infigurabili, in Id., Opera latine conscripta, edited by Fiorentino, v. 1, p. 1, Domenico Morano, Naples 1879, pp. 52-53 (translation by the author).
} 
world $^{23}$; though, their astronomical theories played a minor role in the thought of the Nolan, if compared to those of Copernicus and Tycho Brahe.

\title{
4. ALCHEMY
}

Nevertheless, Geber was still an authority in alchemy and Bruno considered him the founder of this discipline, beside Hermes Trismegistus:

\begin{abstract}
"So this work must be led in accordance with the doctrine of Hermes and Geber. The matter of all metals is Mercury: lead belongs to Saturn, tin to Jupiter, iron to Mars, gold to the Sun, Bronze to Venus, silver to the Moon."24
\end{abstract}

In this and other passages of the Candelaio we find references to the alchemical belief that celestial bodies exercise a dominion on the metals of Earth without any physical contact - not a kind gravitational theory, but still a modern approach to physics. Alchemists applied this principle also to medicine and it is no coincidence that, further on the same quote, Bruno mentions the Persian polymath Ibn Sina (980 - 1037), also known as Avicenna. His Canon of medicine and his commentaries on Aristotelian works were extremely important for the scholastics. Though, it seems that Bruno was not influenced by the philosophy of Avicenna, as he never talked extensively about his thought ${ }^{25}$.

\footnotetext{
${ }^{23}$ There was a Latin "Geber" and a "Geber" whose real name was Jabir ibn Aflah al-Ishbili, an Andalusian astronomer. We believe that Bruno is referring to the "Geber" corresponding to Jabir ibn Hayyan. His source is Pico, who criticized both Geber and al-Battani in a text against astrology. Cfr. Giovanni Pico della Mirandola, Disputationes adversus astrologiam divinatricem, edited by Eugenio Garin, Vallecchi, Florence, 1942, II, p. 324. Regarding al-Battani, he was also known by Nicolaus Copernicus, who quoted him twentythree times in his De revolutionibus orbium coelestium. Cfr. Nidhal Guessoum, "Copernicus and Ibn al-Shatir: Does the Copernican Revolution have Islamic Roots?”, in The Observatory 128 (2008), pp. 231-239. Bruno mentions alBattani in the Ash Wednesday Supper under the name of "Machometto Aracense" with reference to the problem of the variation of equinoxes. We identify him with al-Battani, for "Machometto" derives from Muhammad (one of his prenames) and he lived in al-Raqqah, whence derives "Aracense"; cfr. Giordano Bruno, Cena, I, p. 32. In De immenso, Bruno writes that the estimations of the diameters of the sun and the moon given by alBattani, Ptolemy and Geber are wrong. Cfr. Id., De Immenso, III-V, p. 167: “Audio Bathen Machilinensem inter praecipuos mathematicos referre ad instrumentorum super ea re suspicionem quod Ptolemaeus, Geber et Albategni erraverint (ut ipse multis versuum millibus ostendit) circa quantitatem diametrorum solis et lunae."

${ }^{24}$ Id., Candelaio, edited by Giorgio Bàrberi Squarotti, Einaudi, Turin, 1964, I, XI, pp. 34-35. On the same topics, see also: Ibid., III, I, pp. 56-57. Bruno also talks about certain "Arab astrologers" who tried in vain to extract gold from every metal, for they believed gold to be the spirit of all metals. The Nolan, who agrees primarily with the doctrines of Llull and Geber, considers the theory of those Arabs to be false and makes a distinction between four different categories of metals (instead of one), each of which has its own spirit. Cfr. Id., De Monade, V-III, p. 397.

${ }^{25}$ Avicenna is mentioned other three times in the works of Bruno. In a praise of Paracelsus, the Persian philosopher is listed beside Galen as an auctoritas on medicine (cfr. Id., Causa, III, p. 674). The Nolan also writes that the caliph of Córdoba held Avicenna in esteem (cfr. Id., De Lampade, p. 239), In the Theses de magia, when Bruno talks about the transmitted influence of God on creation, he also refers to Avicenna's theory of intentio, which concerns logic, psychology and metaphysics as well. Cfr. Id., Theses de magia, in Id., Opera latine conscripta, v. 3, p. 458 (translation by the author): "Distinguish between the grade of fundaments and the grade of reality; the grade of fundaments is [that] of the second intentions, as well as the grade of reality is given by the first intentions. The second intentions are based on the first [intentions], logic is connected to the first intentions by the second [intentions]. Avicenna in Liber De sufficientia [i.e. The book of healing]."

Intentions are the objects of linguistic significations. In the Book of healing, the Persian philosopher makes a distinction between the "first notion of intention" (i.e. the sense of a term or sentence) and the "second notion of intention" (i.e. the property that a term or sentence acquires when it is used in attaining knowledge). On this
} 


\section{ISLAMIC PHILOSOPHY}

Beside Avicenna, Bruno mentions other two Muslim philosophers - this time presenting their theories in a more comprehensive way. One of them is Ibn Bajja (c. 1085 - c. 1138), the Latin Avempace. In De immenso, Bruno listed him beside the philosophers who supported the finiteness of the cosmos, as he claimed that the eight celestial sphere contains all the others and it is located per se at the end of the $\operatorname{cosmos}^{26}$. Of course, the Nolan summarized the theory of Avempace in order to criticize it: in his cosmology of infinity, the Aristotelian concept of a last celestial sphere, which cannot be contained by another body, is simply absurd.

Beside Avicenna and Avempace, Bruno knew quite well the Andalusian philosopher Ibn Rushd (1126 - 1198), also known as Averroes. Besides mentioning him quite often in his works, the Nolan was influenced in a consistent way by the thought of the Muslim philosopher of Córdoba. In the following pages, we make a detailed comparison on a theoretical level between these two authors and summarize the main points regarding the Averroism of the Nolan ${ }^{27}$.

In the Middle Ages, Averroes was called "the Commentator" by the scholastics because of his deep knowledge of the Corpus Aristotelicum. Despite of his critical attitude against peritatetics, the Nolan held the Arab philosopher in esteem for his wisdom:

\footnotetext{
"Despite the fact that he [Averroes] was Arab and could not understand Greek, he understood the Aristotelian doctrine better than any other known Greek author; and he would have understood even more, if he hadn't been so addicted to his god Aristotle."28
}

topic, see: Deborah L. Black, "Intentionality in Medieval Arabic Philosophy", in Quaestio 10 (2010), pp. 6581.

${ }^{26}$ Cfr. Giordano Bruno, De Immenso, I, pp. 223-224: “Avempace hispanus, cum Aristotele ultimum coelum octavam sphaeram intelligens stellarum fixarum advectricem, dicit illud esse in loco per accidens, idest, per superficiem proprii corporis convexam, qua septimam, idest, Saturni sphaeram immediate continet, medium respicit universi. [...] Universum vero, sicut et ultimum coelum, est in loco per accidens, nempe non per id quod est extra, sed per id quod est intra: sicque concurrit aperte cum Avempace et Themistio, volens coelum iuxta tertiam significationem immediate esse in loco per superficiem extremam totius quod complectitur [...]" Even Averroes is listed among those "peripatetics" ho claimed that the cosmos is finite. After all, Avempace has been one of his influences. Bruno does not criticise Averroes like in the case of Avempace, because he claimed that "ultimum coelum, est in loco per accidens, nempe non per id quod est extra, sed per id quod est intra"; however, he does not share his view. The only "peripatetic" who is held in esteem by Bruno in this part of $D e$ immenso is Thomas Aquinas, although he was a finitist, too.

${ }^{27}$ Many academics already studied the relation between Bruno and Averroes. In the next pages, we summarize the most relevant contents of the following monographs and articles: Felice Tocco, Le fonti; Rita Sturlese, "«Averroe quantumque arabo et ignorante di lingua greca»: Note sull'Averroismo di Giordano Bruno", in Giornale critico della filosofia Italiana 71 (1992), pp. 248-275; Eugenio Canone, Giordano Bruno lettore di Averroè, in Carmela Baffioni (eds.), Averroes and the Aristotelian Heritage, Guida, Naples, 2004, pp. 211-247; Miguel Angel Granada, "Maquiavelo y Bruno: Religión civil y crítica del Cristianismo", in Bruniana \& Campanelliana 4 (1998), pp. 343-368; Id., “«Esser spogliato dall'umana perfezione e giustizia». Nueva evidencia de la presencia de Averroes en la obra y en el proceso de Giordano Bruno", in Bruniana \& Campanelliana 5 (1999), pp. 305-331; Id., Giordano Bruno. universo infinito, unión con Dios, perfección del hombre, Herder, Bacelona, 2002; Antonio Gagliardi, Scritture e storia: Averroismo e Cristianesimo. Lorenzo de' Medici, Sperone Speroni, Torquato Tasso, Giordano Bruno, Rubbettino, Soveria Mannelli, 1998; Id., Averroismo nel Cinquecento. Da Leone Ebreo a Giordano Bruno, in Matteo Palumbo \& Antonio Saccone (eds.), Tempo e memoria. Studi in ricordo di Giancarlo Mazzacurati, Fridericiana Editrice Universitaria, Naples 2000; Gilberto Sacerdoti, Sacrificio e sovranità. Teologia e politica nell'Europa di Shakespeare e Bruno, Einaudi, Turin, 2002; Massimo Campanini, Giordano Bruno e Averroè: Tematiche a confronto, in Massimiliano Traversino (eds.), Verità e dissimulazione, pp. 45-61.

${ }^{28}$ Id., Causa, IV, pp. 715-716 (translation by the author). Bruno criticizes the philological approach of the 
While the other authors that we mentioned were known by Bruno through secondary sources (with the only exception of Avicenna, maybe), it is almost certain that he read Latin translations of the commentaries of Averroes: in fact, some copies of the renowed Giuntina edition have been found in the library of San Domenico Maggiore in Naples, where the Nolan used to study during his novitiate. Moreover, it is acknowledged that Bruno knew The Incoherence of the Incoherence by Averroes, as he mentions it in De immenso. He probably read the Latin translation (dated 1327) of Calonymos ben Calonymos, a Jew who worked on commission for king Robert of Anjou.

Averroes wrote The incoherence of the incoherence to defend the philosophers against the arguments of al-Ghazali, who criticized Greek philosophical doctrines to support those of theologians; for example, to defend the doctrine of creation ex nihilo, al-Ghazali denied the possibility of the eternity of the world. Averroes claimed that the contraddictions between philosophical and theological doctrines like these are indeed just apparent: according to him, they are basically linguistic problems, which can be solved on the level of denomination (tasmiyya ${ }^{29}$ ). Also Bruno agreed on the eternity of the world and considered the arguments of al-Ghazali to be weak ${ }^{30}$; unlike Averroes, though, he did not make great efforts to harmonize his philosophical theories with those of Christian theologians.

Leaving aside theological controversies, Bruno and Averroes share the same point of view on the function of religion: for both of them, religion is a necessary cultural system for society, especially as regards its moral implications. The Arab wrote that "religious laws are necessary political arts, the principles of which are taken from natural reason and inspiration, especially in what is common to all religions"31 and later Bruno meant the same in The Expulsion of the Triumphant Beast, when the character of Jupiter says: "I don't want that it [the triumphant beast, i.e. the personification of vices] to have the chance to destroy what is excellent and dignified, which consists in what is necessary to the republic of the world $^{\prime 32}$. It is difficult to establish whether Averroes really influenced the Nolan on this point, but their views are the same. Bruno already talked about the practical role of religion in the Ash Wednesday Supper:

humanists, which he considers less efficient than the philosophical one. A similar opinion has been expressed by Pico della Mirandola and later by Vincenzo Colle da Sarno, an early teacher of Bruno. Cfr. Bertrand Levergeois, Giordano Bruno, op. cit., pp. 199-200. Averroes is also mentioned as "a certain Arab [who] stated that the theory of nature in your works [those of Onorio, the reincarnation of Aristotle] is the final effort to show the most clear, pure, high and curious genius ever"; Giordano Bruno, Cabala, II-III, p. 460 (translation by the author).

${ }^{29}$ Cfr. Massimo Campanini, “Giordano Bruno e Averroè”, pp. 47-51.

${ }^{30}$ Cfr. Giordano Bruno, De Immenso, I, pp. 217-218: "Alchazeles arabs mahumetanus theologus, a quo et quidam Christianorum didicere, irrefragabile in libro destructionum [Philosophiae Algazelis] contra aeternitarios adducit argumentum ex eo, quod oporteret infinitos duodecies plures fuisse annos quam menses, trigesies circiter plures menses quam dies, quatuor supra viginti vicibus plures dies quam horas. Unde cadit simile argumentum contra immensitatem universi, et mundorum innumerabilitatem: quia plures essent tellures quam soles, et deinceps alia mille. In cuius puerilis argumenti et omnino (quia est ab extraneo inconvenienti) alieni, solutione in libro destructionis destructionum nescio quam feliciter laboret Averroes. Sed nos hanc stultitiam in iis, quae de minimi existentia et contemplatione dicta sunt, fusius elusimus."

31 Averroes, The Incoherence of the Incoherence, tr. Simon Van den Bergh, retrieved from http://www.muslimphilosophy.com/ir/tt/, 05/08/2017, ch. About the natural sciences IV. Note: this onlinesource is structured into chapters and it does not have page-references.

${ }^{32}$ Giordano Bruno, Spaccio, III-III, p. 384 (translation and italics by the author). On Giordano Bruno and his view about the practical purpose of the religious laws, see also Ibid., I-III, pp. $236 \mathrm{ff}$. 
"[...] that's the reason why philosopher, pontiff and Muslim theologian al-Ghazali claimed that the purpose of [religious] laws isn't the pursuit of truth and speculation, but the goodness of social practice, the profit of civilization, the peaceful coexistence of peoples and the practice for a convenient human dialogue, the preservation of peace and the increase of republics.",33

As Granada points out, here the Nolan quotes al-Ghazali, but this is just "a trick to mention a contrario the real source of Bruno, who's none other than Averroes, he who replied to al-Ghazali in the Destructio destructionum and developed the concept of religion which has been inherited by Bruno through the Latin translation of this work and the Averroistic tradition"34. Averroes was an auctoritas on Aristotelianism, but his own views were still considered to be dangerous by Christian theologians. Averroes got a bad reputation in the West especially after the condemnations of French bishop Tempier against Averroists in 1270 and 1277. We assume that Bruno intentionally replaced him with al-Ghazali, who had a better reputation among the Latins, to get some more attention. Anyway, shall not forget that the purpose of Bruno was mainly to claim that "the true, civil and well-educated philosophers always supported religions, because they knew that faith is required to rule rude peoples which shall be ruled" 35 .

On a practical level, the most effective religious dogma is the belief in life after death - without which religions would not even exist. That principle leads the believers to take a view to what comes after life and consequently behave in accordance with the religious law. Averroes talked about this topic when answering to al-Ghazali, who accused philosophers not to believe in resurrection. The Andalusian philosopher did not make clear if resurrection is corporeal or spiritual only, but he did not deny this dogma. He even supported its validity by stating that such a doctrine is attested by the gospels and by old pagan beliefs, as well ${ }^{36}$ - not to agree with disbelievers, but rather to highlight that in different religions moral systems are grounded on the concept of resurrection:

\begin{abstract}
"But the philosophers in particular, as is only natural, regard this doctrine as most important and believe in it most, and the reason is that it is conducive to an order amongst men on which man's being, as man, depends and through which he can attain the greatest happiness proper to him, for it is a necessity for the existence of the moral and speculative virtuess and of the practical sciences in men. They hold namely that man cannot live in this world without the practical sciences, nor in this and the next world without the speculative virtues, and that neither of these categories is perfected or completed without the practical virtues, and that the practical virtues can only become strong through the knowledge and adoration of God by the services prescribed by the laws of the different religions, like offerings and prayers and supplications and other such utterances by which praise is rendered to God, the angels, and the prophets." 37
\end{abstract}

\footnotetext{
${ }^{33}$ Id., Cena, IV, p. 103 (translation by the author).

${ }^{34}$ Cfr. Miguel Angel Granada, "Maquiavelo y Bruno", p. 356.

${ }^{35}$ Giordano Bruno, De l'infinito, universo e mondi, edited by Jean Seidengart, in Id., Opere italiane, v. 2 , p. 52 (translation by the author).

${ }^{36} \mathrm{Cfr}$. Averroes, The Incoherence of the Incoherence, ch. About the natural sciences IV: "Having finished this question Ghazali begins to say that the philosophers deny bodily resurrection. This is a problem which is not found in any of the older philosophers, although resurrection has been mentioned in different religions for at least a thousand years and the philosophers whose theories have come to us are of a more recent date. The first to mention bodily resurrection were the prophets of Israel after Moses, as is evident from the Psalms and many books attributed to the Israelites. Bodily resurrection is also affirmed in the New Testament and attributed by tradition to Jesus. It is a theory of the Sabaeans, whose religion is according to Ibn Hazm the oldest." ${ }^{37}$ Ivi.
} 
Bruno, who believed in the transmigration of the soul, could not use similar arguments to support his view on the practical role of religion. Anyway, as we have seen before, he stressed the necessity and importance of virtues - even though the principles he wanted to raise to the sky were not the three theological virtues of Christianity. Just like in the case of Averroes, Bruno and the theologians of his time had different views.

Another similarity between these two authors is that they both believed that philosophy makes it possible to conduct a (never-ending) process of improvement in the pursuit of happiness and perfection. However, in their opinion, only an élite of intellectuals is able to seek the truth using the philosophical method; furthermore, such a method shall not be applied by the common people, for it would only lead to misunderstandings. Averroes shared the same idea. On this topic, Bruno mentions the philosopher of Córdoba (again beside alGhazali) in The Heroic Frenzies:

\begin{abstract}
"Here we can find nine reasons to explain why human mind is blind to the divine object [...] The fourth, which is explained in the following lines, isn't as unworthy as the one which arises from the habit to believe to false opinions of the common people, which is disregarded by the opinions of philosophers, or at least arises from the study of pseudophilosophies which are considered to be true by the moltitude as much as they are close to common sense. This habit is one of the greatest and hardest problems which can be found: because (as al-Ghazali and Averroes pointed out) it happens to them something similar to those who used to eat poison since childhood and youth and got used to it $[\ldots]$ and, on the contrary, they refuse what has a good and sweet taste by nature.",38
\end{abstract}

Common people get used to "eat poison": they base their own opinions on common sense, superstition and religion. Apart from their practical role, the Nolan considered religions to be far from the truth. In his view, the only "true religion" is the mythical cult of Hermes Trismegistus, whose wisdom was believed to be the source of the philosophy of Socrates and Plato. Though, only an élite of philosophers can recognize "what has a good and sweet taste" and "the Actaeons who are destined to contemplate the naked Diana are very rare" 39 : that's the reason why the "true arguments [...] are not disclosed by us to common people, but only to the wise men who have the key to understand the meaning of our speeches" 40 . The Nolan makes a distinction between a philosophical and a religious truth in the Averroistic way. As Rita Sturlese points out in her study, the Nolan "inherits from Averroes the concept of theoretical inferiority of religion, even though he's aware of the need of it, or rather of its fundamental role for social life. [...] His refusal to retract his philosophical arguments under request of the Inquisition was also a sign of loyalty to the teaching of Averroes" $"$. In fact, before Bruno, also Averroes made a distinction between philosophers and common people (and theologians as a third category, as well) on the basis of their method of interpretation applied to the sacred scriptures. Philosophers can

\footnotetext{
${ }^{38}$ Giordano Bruno, Furori, IV, pp. 344-347 (translation by the author). By this quote, it is possible that Bruno really believed that al-Ghazali's view was similar to that of Averroes, for some reason. The same poisonmetaphor can be found in other works of Bruno. Cfr. Id., Acrotismus Camoeracensis, in Id., Opera latine conscripta, edited by Francesco Fiorentino, v. 1, p. 1, Domenico Morano, Naples, 1879, p. 58-59: "Sicut enim (adiicit illius Commentator Averroes) qui veneno vesci consueverunt, ea perhibentur facultate praediti, ut tum ipso tamquam proprio cibo reficiantur, tum consequenter quod caeteris est vitale, atque medicina, idipsum sibi exitiale experiantur." As Nicoletta Tirinnanzi points out, the same metaphor is present in other works of the Nolan (also without explicit reference to Averroes). Cfr. Id., Furori, p. 358, n. 51.

${ }^{39}$ Id., Furori, II, p. 300 (translation by the author).

${ }^{40}$ Id., Infinito, I, p. 51 (translation by the author).

${ }^{41}$ Rita Sturlese, "Note sull'Averroismo di Giordano Bruno", p. 275 (translation by the author).
} 
understand the meaning of the text on a deepest level by applying the demonstrative method. In the hands of common people, the same method can only lead to dangerous misunderstandings, for not everyone is able to apply it in a proper way:

"[...] demonstrative method is too difficult for most men, even for those who possess by nature a sound understanding, although such men are very scarce. But to discuss these questions with the masses is like bringing poisons to the bodies of many animals, for which they are real poisons. Poisons, however, are relative, and what is poison for one animal is nourishment for another. The same applies to ideas in relation to men; that is, there are ideas which are poison for one type of men, but which are nourishment for another type. [...] But when the wicked and ignorant transgress and bring poison to the man for whom it is really poison, as if it were nourishment, then there is need of a physician who through his science will exert himself to heal that man, and for this reason we have allowed ourselves to discuss this problem in such a book as this $[\ldots]$ "42

Here we can find the same "poison-metaphor" which was later used by Bruno. Its original meaning is slightly different, though. In fact, there is a difference between the two authors: Averroes was not Averroist, despite of the reputation he got from the $13^{\text {th }}$ century onwards. Unlike Bruno, he would have never agreed with the double-truth theory: in fact, he believed the truth of philosophy and that of the Quran to be the same and he tried to harmonize them. It is not clear whether the Nolan misinterpreted the theory of the Commentator or simply adapted it to his own purposes - most probably his misinterpretation is intentional. Despite of this point of difference, Averroes is surely the most influential Islamic figure in relation to the thought of the Nolan.

\section{CONCLUSION}

Averroism had an important role in the Western philosophical tradition - probably more in the Renaissance, rather than in the Middle Ages, when it was a new cultural phenomenon. Averroism must have had a remarkable influence on Bruno, as we highlighted in the previous paragraph: not only the double-truth theory, but also the doctrine of the unity of the intellect may have a connection with his pantheism and his concept of anima mundi. In fact, the philosophical system of the Nolan is based on the idea that God is nature: according to this premise, God can know nothing else but Himself. Along with the doubletruth theory, also this doctrine has been strongly criticized by bishop Tempier and by Thomas Aquinas, whose position about this topic is clarified in De unitate intellectus contra Averroistas $^{43}$.

Beside Averroes and the authors that we mentioned in the previous pages, we do not know whether the Nolan knew other aspects of the Islamic tradition or not. We analyzed the majority of the explicit references to figures and themes of the Islamic tradition in the works of Giordano Bruno. In conclusion, we can say that his overall picture of Islam is quite vague - the same goes for the most of European intellectuals in the Reinassaince. The Nolan lists Shias and Arabs beside Indians and other peoples of distant lands: it means that the religion and the lifestyle of all these peoples is something exotic in his eyes. Bruno does not know

\footnotetext{
${ }^{42}$ Averroes, The Incoherence of the Incoherence, ch. 7.

${ }^{43}$ In his De unitate intellectus contra Averroistas, Thomas Aquinas criticized the Averroistic double-truth theory and wrongly associated it to Averroes. Anyway, we make clear that Averroes wasn't Averroist, for he never talked about two distinct truths, but only one. For more information about this debate, see: Antonio Petagine, "Il De Unitate Intellectus di Tommaso d'Aquino e la "doppia verità"”' in B@belonline/print 9 (2011), pp. 89-100.
} 
into detail the Islamic doctrine and the only time that he mentions Allah, he apparently does it to support the doctrine of the prisca theologia.

Nevertheless, Bruno showed a remarkable interest in the aspects of Islamic culture which spread in the West: as we have seen before, he had a great esteem for Muslim polymaths like Geber, Avempace and Averroes (not to list the "Arab" Avicebron). He was more interested in the scientific and philosophical aspects of the Islamic tradition, rather than to Islam and its doctrine. In the view of Bruno, the real truth is philosophical, while the religious truth is only relative, for "the same scripture is in the hands of Jews, Christians and Muslims; those cults are so different and conflictual that they give birth to other uncountable very different and conflictual cults, each of which have the purpose which they like the most" 44 .

\section{BIBLIOGRAPHY:}

[1] Averroes, The Incoherence of the Incoherence, tr. Simon Van den Bergh, retrieved from http://www.muslimphilosophy.com/ir/tt/, 05/08/2017;

[2] Black Deborah L., "Intentionality in Medieval Arabic Philosophy", in Quaestio 10 (2010), pp. 65-81;

[3] Giordano Bruno, Acrotismus Camoeracensis, in Id., Opera latine conscripta, edited by F. Fiorentino, v. 1, p. 1, Domenico Morano, Naples, 1879, pp. 53-190;

[4] __ Cabala del cavallo pegaseo, edited by Nicola Badaloni, in Id., Opere italiane, v. 2, Utet, Turin, 2013, pp. 405-485;

[5] ___ Candelaio, edited by Giorgio Bàrberi Squarotti, Einaudi, Turin, 1964;

[6] __ De l'infinito, universo e mondi, edited by J. Seidengart, in Id., Opere italiane, v. 2, Utet, Turin, 2013, pp. 7-167;

[7] __ , De lampade combinatoria lulliana, in Id., Opera latine conscripta, edited by Tocco-Vitelli, v. 2, p. 2, Le Monnier, Florence, 1890, pp. 225-327;

[8] __ _ De la causa, principio et uno, edited by Giovanni Aquilecchia, in Id., Opere italiane, v. 1, Utet, Turin, 2013, pp. 591-746;

[9] __ , De monade, numero et figura, in Id., Opera latine conscripta, edited by F. Fiorentino, v. 1, p. 2, Domenico Morano, Naples, 1879, pp. 323-484;

[10] __ De principiis rerum, elementis et causis, in Id., Opera latine conscripta, edited by ToccoVitelli, v. 3, Le Monnier, Florence, 1891, pp. 505-567;

[11] _ _ De umbris idearum, in Id., Opera latine conscripta, edited by Imbriani-Tallarigo, v. 2, p. 1, Domenico Morano, Naples, 1886, pp. 1-55;

[12] ___, Gli eroici furori, edited by Nicoletta Tirinnanzi, BUR, Milan, 2015;

[13] ___ La cena de le ceneri, edited by Augusto Guzzo, Mondadori, Milan, 2012;

[14] __ Spaccio de la bestia trionfante, edited by Maria Pia Ellero, in Id., Opere italiane, v. 2, Utet, Turin, 2013, pp. 169-404;

[15] _ _ Theses de magia, in Id., Opera latine conscripta, edited by Tocco-Vitelli, v. 3, Le Monnier, Florence 1891, pp. 455-491;

[16] Campanini Massimo, Giordano Bruno e Averroè: Tematiche a confronto, in Massimiliano Traversino (eds.), Verità e dissimulazione. L'infinito di Giordano Bruno tra caccia filosofica e riforma religiosa, Editrice Domenicana Italiana, Naples, 2015, pp. 45-61;

[17] Canone Eugenio, Giordano Bruno lettore di Averroè, in Carmela Baffioni (eds.), Averroes and the Aristotelian Heritage, Guida, Naples, 2004, pp. 211-247;

[18] Ciliberto Michele, Giordano Bruno, Laterza, Rome-Bari, 2005;

[19] Levergeois Bertrand, Giordano Bruno, tr. Manuela Maddamma, Fazi Editore, Rome, 2013;

[20] Gagliardi Antonio, Averroismo nel Cinquecento. Da Leone Ebreo a Giordano Bruno, in Matteo [23] Palumbo \& Antonio Saccone (eds.), Tempo e memoria. Studi in ricordo di Giancarlo Mazzacurati, Fridericiana Editrice Universitaria, Naples 2000;

${ }^{44}$ Id., Cena, Ibid., IV, pp. 106-107 (translation by the author). Bruno also defines the Christian doctrine as "mother of all frauds". Cfr. Id., Spaccio, I-III, p. 238. 
[21] __ Scritture e storia: Averroismo e Cristianesimo. Lorenzo de' Medici, Sperone Speroni, Torquato Tasso, Giordano Bruno, Rubbettino, Soveria Mannelli, 1998;

[22] Garin Eugenio, Lo Zodiaco della vita. La polemica sull'astrologia dal Trecento al Cinquecento, Laterza, Rome-Bari, 2007;

[23] Giovanni Pico della Mirandola, Disputationes adversus astrologiam divinatricem, edited by Eugenio Garin, Vallecchi, Florence, 1942;

[24] Granada Miguel Angel, "Il rifiuto della distinzione fra potentia absoluta e potentia ordinata di Dio e l'affermazione dell'universo infinito in Giordano Bruno", in Rivista di Storia della Filosofia 49/3 (1994), pp. 495-532;

[25] __ "Maquiavelo y Bruno: Religión civil y crítica del Cristianismo", in Bruniana \& Campanelliana 4 (1998), pp. 343-368;

[26] ___ "«Esser spogliato dall'umana perfezione e giustizia». Nueva evidencia de la presencia de Averroes en la obra y en el proceso de Giordano Bruno", in Bruniana \& Campanelliana 5 (1999), pp. 305-331;

[27] _ Giordano Bruno. Universo infinito, unión con Dios, perfección del hombre, Herder, Bacelona 2002;

[28] Guessoum Nidhal, "Copernicus and Ibn al-Shatir: Does the Copernican Revolution have Islamic Roots?", in The Observatory 128 (2008), pp. 231-239;

[29] Ibn Khaldun, The Muqaddimah, tr. Franz Rosenthal, v. 2, Routledge \& Paul, London, 1958;

[30] Idel Moshe, "Johannes Reuchlin: Kabbalah, Pythagorean Philosophy and Modern Scholarship", in Studia Judaica 16 (2008), pp. 30-55;

[31] Marsilio Ficino, The Philebus Commentary, tr. M. J. B. Allen, University of California Press, Berkeley, 1975;

[32] Nasr Seyyed Hossein, Science and Civilization in Islam, New American Library, New York, 1968 ;

[33] Petagine Antonio, "Il De Unitate Intellectus di Tommaso d'Aquino e la "doppia verità"”, in B@belonline/print 9 (2011),pp.89-100;

[34] Sacerdoti Gilberto, Sacrificio e sovranità. Teologia e politica nell'Europa di Shakespeare e Bruno, Einaudi, Turin, 2002;

[35] Spampanato Vincenzo, Vita di Giordano Bruno: con documenti editi e inediti, v. 1-2, Principiato Editore, Messina, 1921;

[36] Samsó Julio, Al-Andalus, a Bridge between Arabic and European Science, in Alhadra 1 (2015), pp. 101-125;

[37] Sturlese Rita, "«Averroe quantumque arabo et ignorante di lingua greca»: Note sull'Averroismo di Giordano Bruno", in Giornale critico della filosofia italiana 71 (1992), pp. 248-275;

[38] Tocco Felice, "Le fonti più recenti della filosofia del Bruno", in Rendiconti della R. Accad. dei Lincei. Classe di scienze morali, storiche e filologiche 1-7/8 (1892), pp. 503-621;

[39] Traversino Massimiliano, Sovranità in controluce. Bruno, Gentili e il dibattito cinquecentesco sulla Condizione dei nativi americani, in Id. (eds.), Verità e dissimulazione. L'infinito di Giordano Bruno tra caccia filosofica e riforma religiosa, Editrice Domenicana Italiana, Naples, 2015, pp. 411-505;

[40] Yates Frances Amelia, Giordano Bruno and the Hermetic Tradition, Routledge and Kegan Paul, London, 1964;

[41] Zambon Francesco \& Grossato Alessandro, Il mito della fenice in Oriente e in Occidente, Marsilio, Venice, 2004. 